\title{
Effects of cysteine addition and heat treatment during non-fat dry milk processing on the plasmin enzyme system
}

\author{
Devon DuRKeE, Kirby HaYes* \\ Department of Food Science, Purdue University, West Lafayette, IN 47907, USA
}

\begin{abstract}
The objective of this study was to measure the effects of cysteine addition and heat treatment on plasmin (PL) activity and plasminogen (PG) activation in reconstituted non-fat dry milk (NFDM). Cysteine was added to a final concentration of $0.16 \mathrm{mg} \cdot \mathrm{mL}^{-1}$ to raw, defatted milk and pasteurized at $72{ }^{\circ} \mathrm{C}$ for $15 \mathrm{~s}$ (low heat, $\mathrm{LH}$ ) or $100^{\circ} \mathrm{C}$ for $30 \mathrm{~s}$ (medium heat, $\mathrm{MH}$ ) prior to spray drying. Both MH fluid milk and NFDM had no PL activity or PG activation, regardless of cysteine addition. For both LH fluid milk and NFDM, there was a significant decrease in PL activity upon cysteine addition $(P<0.0001$ for both), as well as in PG activation $(P=0.0003$ for fluid milk, $P<0.0001$ for NFDM), likely due to the polymerization of PG or binding of PL and PG with other milk proteins. Upon storage of reconstituted powders at $21^{\circ} \mathrm{C}$ and $4{ }^{\circ} \mathrm{C}$, PL activity increased with a complimentary decrease in PG-derived PL activity in LH samples, though these changes slowed in samples with added cysteine. Urea-PAGE showed proteolysis of $\beta$-casein consistent with PL activities in LH samples. No PL or PG-derived PL activities or proteolysis were observed in stored MH samples. These results suggest that the addition of cysteine prior to the pasteurization and manufacture of LH-NFDM significantly decreases the potential for proteolysis during storage of reconstituted powder caused by the PL enzyme system.
\end{abstract}

\section{plasmin / plasminogen / cysteine / heat treatment / non-fat dry milk}

摘要 - 脱脂乳粉生产过程中半胱氨酸和热处理对血浆酶系的影响。本研究目的是测定 添加半胱氨酸和热处理对还原脱脂乳中血浆酶 (PL) 活性的影响和对血浆酶原 (PG) 的激 活。在脱脂原料乳中添加 $0.16 \mathrm{mg} \cdot \mathrm{mL}^{-1}$ 的半胱氨酸, 先经过 $72{ }^{\circ} \mathrm{C} 、 15 \mathrm{~s}$ (低热处理) 和 $100{ }^{\circ} \mathrm{C} 、 30 \mathrm{~s}$ (中度热处理) 的巴氏杀菌, 然后进行喷雾干燥。如果不考虑半胱氨酸的添加, 在中度热处理的液态奶及其干燥脱脂粉中都没有检测到血浆酶活性和血浆酶原的激活。

而在低热处理的液态奶及其干燥的脱脂粉中, 两个样品中血浆酶活性均随着半胱氨酸的添 加呈显著性的降低 $(P<0.0001)$, 同样两个样品中血浆酶原的激活趋势也相同 (液态奶的 $P=0.0003$, 干燥脱脂粉的 $P<0.0001$ ), 产生着种现象的原因可能是由于血浆酶原的聚合或 者血浆酶和血浆酶原与乳中其他蛋白质结合在一起。将还原的脱脂奶分别在 $21^{\circ} \mathrm{C}$ 和 $4{ }^{\circ} \mathrm{C}$ 下聍藏, 在低热处理的样品中, 血浆酶的活性和源于血浆酶原的血浆酶活性显著地增加, 但是 在添加了半胱氨酸的样品中, 则显著地抑制了血浆酶的活性。Urea-PAGE 证明了 $\beta$-酪蛋白 的水解程度与低热处理样品中血浆酶的活性一致。在䛎藏的中度热处理样品中, 没有检测到 血浆酶或源于血浆酶原的血浆酶活性, 也没有检测到蛋白质的水解。上述试验结果证明预先 在脱脂原料乳中添加半胱氨酸, 然后采用低热巴氏杀菌处理和喷雾干燥生产脱脂粉, 这一加 工过程可以显著地降低还原脱脂奶在䛎藏过程中由于血浆酶系造成的蛋白水解。

血浆酶 / 血浆酶原 / 半胱氨酸 / 热处理 / 脱脂乳粉

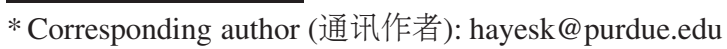




\begin{abstract}
Résumé - Effets de l'addition de cystéine et du traitement thermique au cours de la fabrication de poudre de lait écrémé sur le système enzymatique plasmine. L'objectif de cette étude était de mesurer les effets de l'addition de cystéine et du traitement thermique sur l'activité de la plasmine et sur l'activation du plasminogène dans des laits écrémés en poudre reconstitués. La cystéine était ajoutée à une concentration finale de $0,16 \mathrm{mg} \cdot \mathrm{mL}^{-1}$ à du lait cru écrémé et pasteurisé à $72^{\circ} \mathrm{C}-15 \mathrm{~s}$ ("low heat", $\mathrm{LH}$ ) ou $100^{\circ} \mathrm{C}-30 \mathrm{~s}$ ("medium heat", $\mathrm{MH}$ ) avant séchage par atomisation. Le lait $\mathrm{MH}$ n'avait pas d'activité plasmine ou d'activation du plasminogène, indépendamment de l'addition de cystéine. Pour le lait LH, il y avait une diminution significative de l'activité plasmine après addition de cystéine $(P<0,0001)$, ainsi que de l'activation du plasminogène $(P=0,0003$ pour le lait avant séchage, $P<0,0001$ pour le lait reconstitué), probablement due à la polymérisation du plasminogène ou à la liaison de la plasmine et du plasminogène à d'autres protéines laitières. Au cours du stockage à $21^{\circ} \mathrm{C}$ et $4{ }^{\circ} \mathrm{C}, 1^{\prime}$ activité plasmine augmentait tandis que celle dérivée du plasminogène diminuait dans les échantillons LH, ces changements étant cependant radicalement ralentis dans les échantillons avec ajout de cystéine. L'électrophorèse urée-PAGE montrait une protéolyse de la caséine $\beta$ en accord avec les activités plasmine dans les échantillons LH. Aucune activité plasmine ou plasmine dérivée du plasminogène ou protéolyse n'était observée dans les échantillons MH au cours du stockage. Ces résultats suggèrent que l'addition de cystéine avant la pasteurisation et la fabrication de poudre LH diminue significativement le risque de protéolyse due au système enzymatique plasmine du lait reconstitué, au cours du stockage de la poudre.
\end{abstract}

\title{
plasmine / plasminogène / cystéine / traitement thermique / poudre de lait écrémé
}

\section{INTRODUCTION}

Non-fat dry milk (NFDM) is a widely used dairy ingredient in the food industry, with applications varying from baked goods and confections to soups and sauces [21]. Non-fat dry milk is manufactured by preheating, concentrating, and spray drying pasteurized skim milk [14], which often is reconstituted to produce ultra-high temperature (UHT) milk [19] or utilized for its functional properties in other food formulations. Depending upon the preheat treatment that fluid milk receives during processing, the reconstituted powder exhibits varying degrees of water absorption, emulsion stability, and gelation [22]. Heat treatment of NFDM is classified according to the whey protein nitrogen index [14], as more whey proteins, specifically $\beta$-lactoglobulin, bind to caseins with increasing temperatures $[18,21,26]$.

Proteolysis of milk proteins, specifically $\alpha$-and $\beta$-casein, has both positive and negative effects on the quality of milk and dairy products. While proteolysis often is caused by bacterial proteases, milk of high microbiological quality still can undergo proteolysis due to the indigenous plasmin (PL) enzyme system [5, 15,24]. This system consists of plasminogen (PG), the inactive zymogen, which is converted to active PL (EC 3.4.21.7), a serine proteinase, by the action of plasminogen activators (PA), both tissue-type (tPA) and urokinasetype (uPA). Plasmin mainly hydrolyzes $\beta$-casein, causing various effects on the quality of dairy products, such as cheese and yogurt, which have been previously reported in the literature $[6,10,15,20]$. Plasmin clearly has been shown to survive high temperature, short time $\left(72{ }^{\circ} \mathrm{C}, 15 \mathrm{~s}\right)$ pasteurization conditions [24], though decreases in PL activity and PG activation have been found in milk processed at higher temperatures because of disulfide interactions between PL system components and $\beta$-lactoglobulin [26]. However, PG concentrations in fluid milk are 2-20 times that of PL [24]; thus, controlling the activation of PG is of utmost importance for maintaining the quality of stored dairy products.

Prior research has shown that reconstituted milk powders are capable of undergoing PL-like proteolysis [19]. However, research on $\mathrm{PG}$ activation in reconstituted 
powders has not been reported. This is of particular importance, since activation of PG in powders would increase PL levels, potentially resulting in reduced quality. Prior research in our laboratory has shown that the addition of cysteine before thermal treatment essentially eliminates PL activity and PG activation in model systems and fluid milk due to induced thiol-disulfide interchange reactions, resulting in the polymerization of PG [30]. Thus, cysteine addition may provide a means of controlling PL-induced proteolysis in dairy products. However, the effect of cysteine addition on PL system components in NFDM has not been studied previously. Therefore, the objective of our study was to measure the effects of cysteine addition and heat treatment on PL activity and PG activation in reconstituted NFDM.

\section{MATERIALS AND METHODS}

\subsection{Materials and sources}

Bovine PL (5 U.mL ${ }^{-1}$, \#602370) was obtained from Roche Applied Science (Indianapolis, IN, USA). Bovine PG (\#416), human urokinase (uPA, \#124),

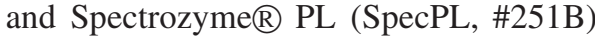
were obtained from American Diagnostica (Stamford, CT, USA). Solutions of PL, PG, uPA, and SpecPL were prepared in modified tris buffer (MTB, $0.1 \mathrm{~mol} \cdot \mathrm{L}^{-1}$ sodium chloride, $0.05 \mathrm{~mol} \cdot \mathrm{L}^{-1}$ tris, $0.01 \%$ Tween 80, pH 7.6). A micro bicinchoninic acid (BCA) protein assay kit (\#23235) was obtained from Pierce Biotechnology (Rockford, IL, USA). Acrylamide (40\% with bis, \#161-0148), Criterion empty gel cassettes (18-well, \#345-9902; and 26-well, \#345-9903), Criterion tris- $\mathrm{HCl}$ 10.5-14\% gradient precast gels (\#3459949), $10 \mathrm{X}$ tris/glycine running buffer (\#161-0771), $10 \mathrm{X}$ tris/glycine/SDS running buffer (\#161-0732), Laemmli buffer (\#161-0737), pre-stained broad range molecular weight standards (\#1610318), ammonium persulfate (APS, \#161-0700), and N,N,N',N'-tetramethyl1,2-ethanediamine (TEMED, \#161-0801) were obtained from Bio-Rad Laboratories (Hercules, CA, USA). $\beta$-casein (\#C6905), $\beta$-lactoglobulin (\#L3908), $\quad \kappa$-casein (\#C0406), $\beta$-mercaptoethanol (\#M7154), and cysteine (\#C8755) were obtained from Sigma-Aldrich (St. Louis, MO, USA). Aerobic plate count petrifilms (\#6400) were obtained from 3M Microbiology (St. Paul, MN, USA). Fresh raw milk was obtained from the Purdue University Dairy Research and Education Center (West Lafayette, IN, USA).

\subsection{Experimental designs and milk preparation}

\subsubsection{Study 1: Comparison of liquid and non-fat dry milk}

Fresh raw milk was collected in triplicate, defatted, and divided into two aliquots. Cysteine was added to one aliquot to a final concentration of $0.16 \mathrm{mg} \cdot \mathrm{mL}^{-1}$. Each aliquot was further divided into two aliquots and pasteurized at $72{ }^{\circ} \mathrm{C}$ for $15 \mathrm{~s}$ (low heat treatment, LH) or $100{ }^{\circ} \mathrm{C}$ for $30 \mathrm{~s}$ (medium heat treatment, $\mathrm{MH}$ ). Total plate counts were completed for raw and pasteurized milk samples according to AOAC Official Method 986.33 [4]. Milk samples then were spray dried using a Niro mobile minor spray dryer (Copenhagen, Denmark) with inlet and outlet temperatures of $120{ }^{\circ} \mathrm{C}$ and $80{ }^{\circ} \mathrm{C}$, respectively. Heat classification of the milk powders was determined using the whey protein nitrogen index assay [2]. Both liquid milk and NFDM samples were retained for enzymatic activity analyses. NFDM samples were reconstituted to $10 \% \mathrm{w} / \mathrm{v}$ in deionized-distilled water (DDW) prior to analysis. 


\subsubsection{Study 2: Storage study of reconstituted non-fat dry milk}

All NFDM samples prepared according to Section 2.2.1 (LH, LH with cysteine, $\mathrm{MH}$, and $\mathrm{MH}$ with cysteine) were reconstituted, in duplicate, to $10 \% \mathrm{w} / \mathrm{v}$ in $0.02 \% \mathrm{w} / \mathrm{v}$ sodium azide (to prevent microbial growth) and dosed with uPA to a final concentration of 0 or $1 \mathrm{IU} \cdot \mathrm{mL}^{-1}$. Plasmin activity, PG-derived PL activity, and $\beta$-casein hydrolysis were measured at 0,5 and 10 days after storage at $21^{\circ} \mathrm{C}$, and at 0 , 2 and 4 weeks after storage at $4{ }^{\circ} \mathrm{C}$. Total plate counts were completed for all samples at the beginning and end of storage at both temperatures.

\subsection{Enzymatic activity assays}

Liquid milk and reconstituted NFDM samples were prepared in triplicate (Study 1) or duplicate (Study 2) for analysis using the method of Richardson and Pearce [25] with minor modifications. The milk samples $(0.75 \mathrm{~mL})$ were vortexed with $0.4 \mathrm{~mol} \cdot \mathrm{L}^{-1}$ trisodium citrate $(0.25 \mathrm{~mL})$ in an Eppendorf tube $(1.5 \mathrm{~mL}$ capacity) and incubated for $15 \mathrm{~min}$ at $37{ }^{\circ} \mathrm{C}$. The samples were centrifuged in the Eppendorf tubes at $15600 \times g$ for $15 \mathrm{~min}$, and the supernatant was retained for activity analyses.

To measure PL and PG-derived PL activities, chromogenic activity assays were carried out according to the method of Fajardo-Lira and Nielsen [8] with modifications. For the PL activity assay, supernatant samples $(100 \mu \mathrm{L})$ were mixed with $1.6 \mathrm{mmol} \cdot \mathrm{L}^{-1}$ SpecPL $(300 \mu \mathrm{L})$ in Eppendorf tubes. For the PG-derived PL activity assay, supernatant samples $(100 \mu \mathrm{L})$ were mixed with $3.2 \mathrm{mmol} \cdot \mathrm{L}^{-1}$ SpecPL $(100 \mu \mathrm{L}), 280 \quad \mathrm{IU} \cdot \mathrm{mL}^{-1} \mathrm{uPA}$ $(100 \mu \mathrm{L})$, and MTB $(100 \mu \mathrm{L})$. Both PL and PG-derived PL assay samples were incubated for $1 \mathrm{~h}$ at $37^{\circ} \mathrm{C}$ and centrifuged at $15600 \times g$ for $5 \mathrm{~min}$. Supernatant from the PL and PG-derived PL assay samples $(100 \mu \mathrm{L})$ were pipetted in triplicate into a 96-well microtiter plate and the absorbance was read at $405 \mathrm{~nm}$ and $490 \mathrm{~nm}$ with a $\mathrm{V}_{\max }$ kinetic plate reader (Molecular Devices Co., Menlo Park, CA, USA). The absorbance at $490 \mathrm{~nm}$ was subtracted from the absorbance at $405 \mathrm{~nm}$ to correct for turbidity. The absorbance values then were converted to PL and PG concentrations (in $\mu \mathrm{g} \cdot \mathrm{mL}^{-1}$ ) using standard curves [8]. A micro BCA assay was performed on PL used in the standard curve according to the manufacturer's directions to convert $\mathrm{U} \mathrm{PL} \cdot \mathrm{mL}^{-1}$ to $\mu \mathrm{g} \mathrm{PL} \cdot \mathrm{mL}^{-1}$. For $\mathrm{PG}$ determination, the absorbance value was corrected by subtracting the absorbance obtained from the PL assay to account for pre-existing PL activity in the tested sample.

\subsection{Two-dimensional alkaline/SDS- PAGE}

Two-dimensional electrophoresis was employed, using alkaline-PAGE in the first dimension and SDS-PAGE under reducing conditions in the second dimension, following similar methods published previously by Havea et al. [12] and Manderson et al. [17] to analyze milk protein complexes formed during heating and processing of NFDM. Reconstituted NFDM samples (10 $\mu \mathrm{L})$ were added to $240 \mu \mathrm{L}$ of alkaline-PAGE sample buffer $\left(20 \% \mathrm{v} / \mathrm{v} 0.5 \mathrm{~mol} \cdot \mathrm{L}^{-1}\right.$ tris, $\mathrm{pH} 6.8$; $8 \% \mathrm{v} / \mathrm{v}$ glycerol; $0.009 \% \mathrm{w} / \mathrm{v}$ bromophenol blue). Samples ( $35 \mu \mathrm{L})$ were loaded onto $10.5-14 \%$ gradient tris- $\mathrm{HCl}$ gels and electrophoresed in $10 \mathrm{X}$ tris/glycine running buffer (diluted 1:10 $\mathrm{v} / \mathrm{v}$ with DDW) at $200 \mathrm{~V}$ for $60 \mathrm{~min}$. Individual lanes from the gels were excised, boiled for $5 \mathrm{~min}$ in SDS-PAGE reducing sample buffer $\left(62.5 \mathrm{mmol} \cdot \mathrm{L}^{-1}\right.$ tris $\mathrm{HCl}$, $2 \% \mathrm{v} / \mathrm{v}$ sodium dodecyl sulfate, $25 \% \mathrm{v} / \mathrm{v}$ 
Table I. Urea-PAGE gel formulation.

\begin{tabular}{lcc}
\hline Ingredients & Resolving gel (10\%) & Stacking gel (4.2\%) \\
\hline Deionized distilled water, mL & 1.2 & - \\
Resolving buffer $^{1}, \mathrm{~mL}$ & 14 & - \\
Stacking buffer $^{2}, \mathrm{~mL}$ & - & 9 \\
Acrylamide $^{3}(40 \% \mathrm{w} / \mathrm{v}), \mathrm{mL}$ & 4.8 & 1 \\
$\mathrm{TEMED}^{4}, \mu \mathrm{L}$ & 10 & 10 \\
$\mathrm{APS}^{5}, \mu \mathrm{L}$ & 80 & 50 \\
Total volume, $\mathrm{mL}$ & 20.09 & 10.06 \\
\hline
\end{tabular}

${ }^{1}$ Resolving buffer $=6.43 \mathrm{~mol} \cdot \mathrm{L}^{-1}$ urea, $0.557 \mathrm{~mol} \cdot \mathrm{L}^{-1}$ tris, $0.056 \mathrm{~mol} \cdot \mathrm{L}^{-1} \mathrm{HCl}, \mathrm{pH} 8.9$.

${ }^{2}$ Stacking buffer $=5 \mathrm{~mol} \cdot \mathrm{L}^{-1}$ urea, $0.067 \mathrm{~mol} \cdot \mathrm{L}^{-1}$ tris, $0.044 \mathrm{~mol} \cdot \mathrm{L}^{-1} \mathrm{HCl}, \mathrm{pH}$ 7.6.

${ }^{3} 40 \% \mathrm{w} / \mathrm{v}$ Acrylamide/bis solution $(2.6 \% \mathrm{C})$.

${ }^{4}$ TEMED $=\mathrm{N}, \mathrm{N}, \mathrm{N}$ ',N'-tetramethyl-1,2-ethanediamine.

${ }^{5} \mathrm{APS}=10 \% \mathrm{w} / \mathrm{v}$ ammonium persulfate, prepared fresh.

glycerol, $0.5 \% \quad \mathrm{v} / \mathrm{v} \quad \beta$-mercaptoethanol, trace bromophenol blue, $\mathrm{pH}$ 6.8), and set into a SDS-PAGE gel according to Larson et al. [16]. Protein standards of $\beta$-lactoglobulin, $\kappa$-casein, PL, and PG were prepared by making $0.25 \mathrm{mg} \cdot \mathrm{mL}^{-1}$ solutions in DDW of each protein. An aliquot of each protein standard solution $(100 \mu \mathrm{L})$ was diluted with Laemmli buffer $(190 \mu \mathrm{L})$ and $\beta$-mercaptoethanol $(10 \mu \mathrm{L})$ and boiled for $5 \mathrm{~min}$. Molecular weight standards $(5 \mu \mathrm{L})$ and individual protein standards $(10 \mu \mathrm{L})$ were loaded onto the gels in addition to the alkaline PAGE strip previously set in the stacking gel. Gels then were electrophoresed at $200 \mathrm{~V}$ for $60 \mathrm{~min}$, stained with Coomassie blue $(50 \% \mathrm{v} / \mathrm{v}$ methanol, $10 \% \mathrm{v} / \mathrm{v}$ glacial acetic acid, $0.25 \% \mathrm{w} / \mathrm{v}$ Coomassie Brilliant Blue G-250) for $1 \mathrm{~h}$ and destained (10\% v/v glacial acetic acid, $5 \% \mathrm{v} / \mathrm{v}$ methanol) overnight [9].

\subsection{Urea-PAGE and $\beta$-casein hydrolysis}

Urea-PAGE analysis of the milk samples was used to quantify $\beta$-casein according to the method of Andrews [3] with modifications. Standard solutions of $0.4,0.6,0.8$ and $1.0 \% \mathrm{w} / \mathrm{v} \beta$-casein were prepared, in triplicate, using DDW, diluted 1:25 with sample buffer $\left(8 \mathrm{~mol} \cdot \mathrm{L}^{-1}\right.$ urea, $0.06 \mathrm{~mol} \cdot \mathrm{L}^{-1}$ tris, $0.04 \mathrm{~mol} \cdot \mathrm{L}^{-1} \mathrm{HCl}$, $0.1 \mathrm{~mol} \cdot \mathrm{L}^{-1} \beta$-mercaptoethanol, trace bromophenol blue, $\mathrm{pH}$ 8.9), and boiled for 5 min. Reconstituted NFDM samples $(5 \mu \mathrm{L})$ were prepared in triplicate by dilution with DDW $(5 \mu \mathrm{L})$ and sample buffer $(240 \mu \mathrm{L})$ and also were boiled for 5 min. Standards and samples $(10 \mu \mathrm{L})$ were loaded onto hand-cast urea gels (Tab. I). The gels were electrophoresed in $10 \mathrm{X}$ tris/glycine running buffer (diluted $1: 10 \mathrm{v} / \mathrm{v}$ with DDW) at $200 \mathrm{~V}$ for 60-90 min. Gels then were stained and destained as previously described in Section 2.4. Destained gels were scanned using a Bio-Rad Laboratories GS-800 densitometer. Peak optical density of $\beta$-casein bands were analyzed, after subtracting the background density, using QuantityOne 1-D software (version 4.5.1, Bio-Rad Laboratories). The densities of the $\beta$-casein bands for the reconstituted NFDM samples were converted to concentrations using the standard curve.

\subsection{Statistical analysis}

Data were analyzed using the general linear model and mixed procedures of SAS 
version 9.1 [27]. For data from Study 1, a 2-way analysis of variance (ANOVA) was used to test the main effects (heat treatment and cysteine addition) and interaction for significance. For data from Study 2, a 3-way repeated measures ANOVA was used to test the main effects (heat treatment, cysteine addition, uPA addition, and time) and all possible interactions for significance. The Tukey-Kramer multiple means comparison test was used to compare means at $95 \%$ confidence when the model was shown to be significant $(P \leqslant$ $0.05)$. Results for all analyses were considered significant if $P \leqslant 0.05$.

\section{RESULTS AND DISCUSSION}

\subsection{Study 1: Comparison of liquid and non-fat dry milk}

Total plate counts for raw and pasteurized fluid milk were below $10^{4}$ and $10^{3} \mathrm{CFU} \cdot \mathrm{mL}^{-1}$, respectively (data not shown), demonstrating the milk was of good microbiological quality. Whey protein nitrogen index results confirmed that the milk samples heated at $72{ }^{\circ} \mathrm{C}$ for $15 \mathrm{~s}$ or $100{ }^{\circ} \mathrm{C}$ for $30 \mathrm{~s}$ yielded LH- and $\mathrm{MH}$ NFDM, respectively (data not shown).

For both liquid and powder samples, the interaction between heat treatment and cysteine addition was significant for PL activity $(P<0.0001$ for both), as well as for PG-derived PL activity $(P=$ 0.0003 and $P<0.0001$, respectively). The addition of cysteine significantly decreased PL and PG-derived PL activities in LH fluid milk and reconstituted NFDM (Fig. 1), likely due to the polymerization of PG as previously shown by Stevenson [30]. However, MH fluid milk and reconstituted NFDM showed no PL or PG-derived PL activity, regardless of cysteine addition (Fig. 1). This observation is likely due to the denaturation of whey proteins at high temperatures, specifically $\beta$-lactoglobulin [21]. The unfolding of $\beta$-lactoglobulin exposes a free sulfhydryl group that binds to $\mathrm{PL}$ and $\mathrm{PG}$ via sulfhydryl/disulfide interchanges, thus rendering it inactive, which has been demonstrated by several authors $[1,18,26]$. The addition of cysteine decreased PL and PGderived activities without higher heat treatments, as in the LH fluid milk and NFDM, because cysteine initiates thiol-disulfide interchange reactions, resulting in polymerization of PG or binding of PL and PG with other free sulfhydryls in milk proteins. However, heat is necessary to induce this reaction, as the addition of cysteine without heat did not inactivate PL or PG in model systems [30]. This could be because PG must be heated in excess of $62{ }^{\circ} \mathrm{C}$ to unfold and expose its disulfide bonds [7].

Two-dimensional gel electrophoresis of reconstituted NFDM samples revealed several protein agglomerates, especially within the second band from the 1-dimensional gel strip (Fig. 2). In both LH samples, a band parallel with the PG standard was present near the middle of the 1-dimensional strip, corresponding with band 2 in the 1-dimensional gel. Additionally, there was another band with similar molecular weight as the PG standard for the LH control sample (circled), corresponding to band 1 in the 1-dimensional gel, while this band was not present in the LH sample with cysteine. The difference in band patterns between the LH samples with and without cysteine could indicate that PG binds with other milk proteins when heated with cysteine, resulting in the observed decrease in PG-derived PL activity. Also present in band 1 from the 1-dimensional gel was $\kappa$-casein, which might have been associated with PG. This is consistent with findings that PL and PG are known to associate with casein micelles, of which $\kappa$-casein constitutes the exterior [5]. Cysteine addition might have disrupted any association between 
(A)
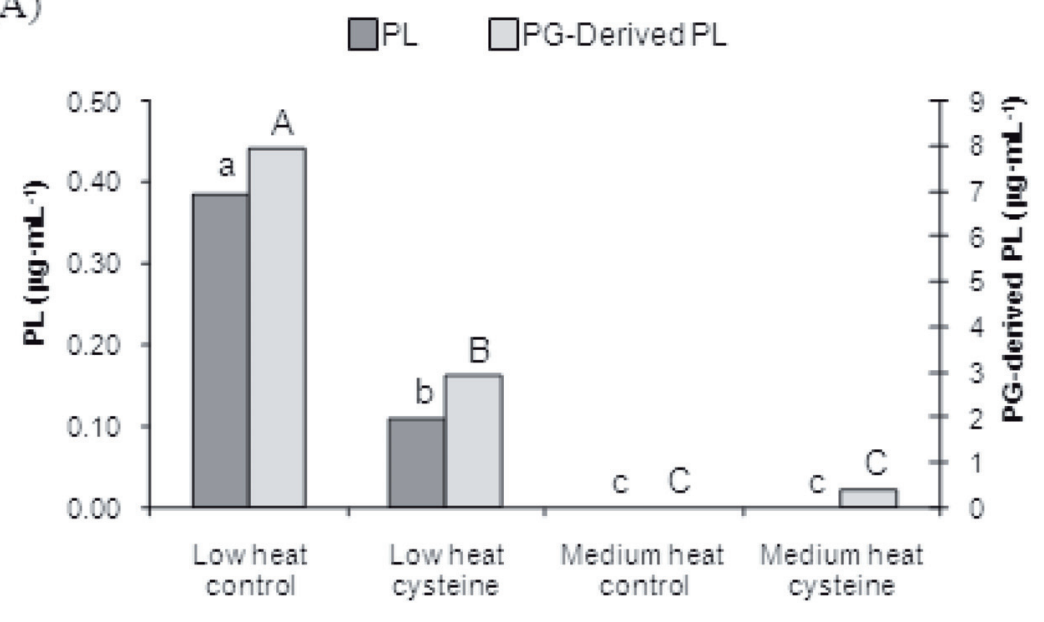

(B) $\square \mathrm{PL} \quad \square \mathrm{PG}$-derivedPL

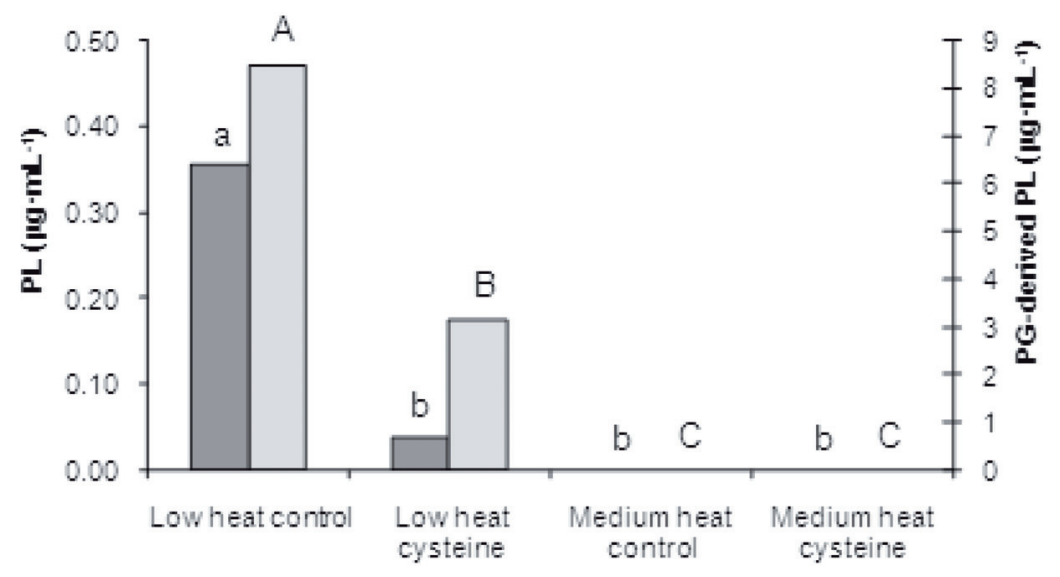

Figure 1. Plasmin (PL) and plasminogen (PG)-derived PL in low and medium fluid milk (A) and reconstituted NFDM (B). Bars represent the mean of triplicate results. Within each graph, lower case letters indicate statistical significance for PL, while upper case letters indicate statistical for PG-derived PL $(P \leqslant 0.05)$.

$\kappa$-casein and PG, allowing PG to participate in disulfide linkages with itself or other proteins. However, it cannot be ascertained from the 2-dimensional gels whether PG polymerized or bound with other milk proteins. While PG polymerizes in a model system [30], it is more likely that PG bound with other milk proteins, as each PG molecule would have a greater chance of coming into contact with casein 
(A)

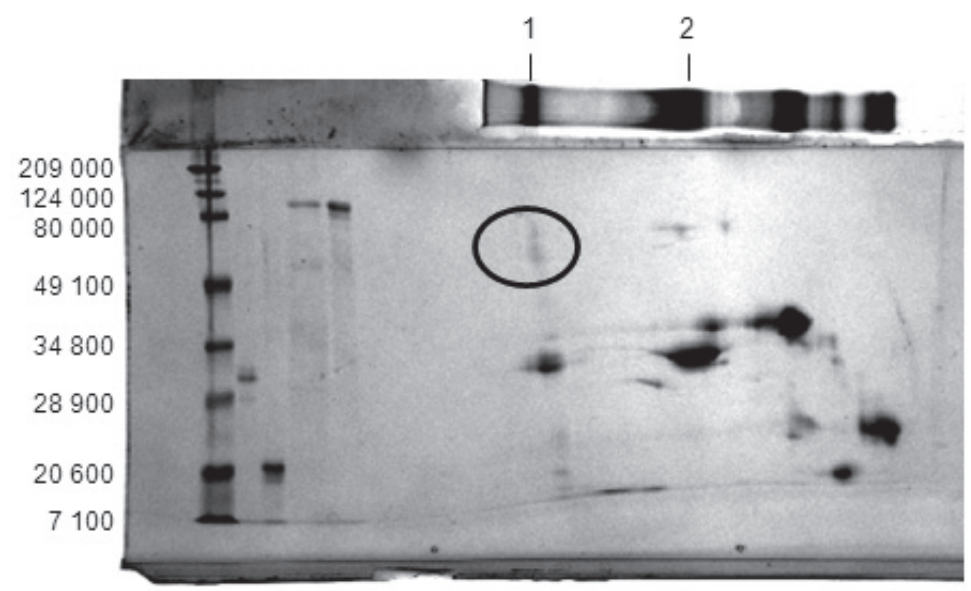

(B)

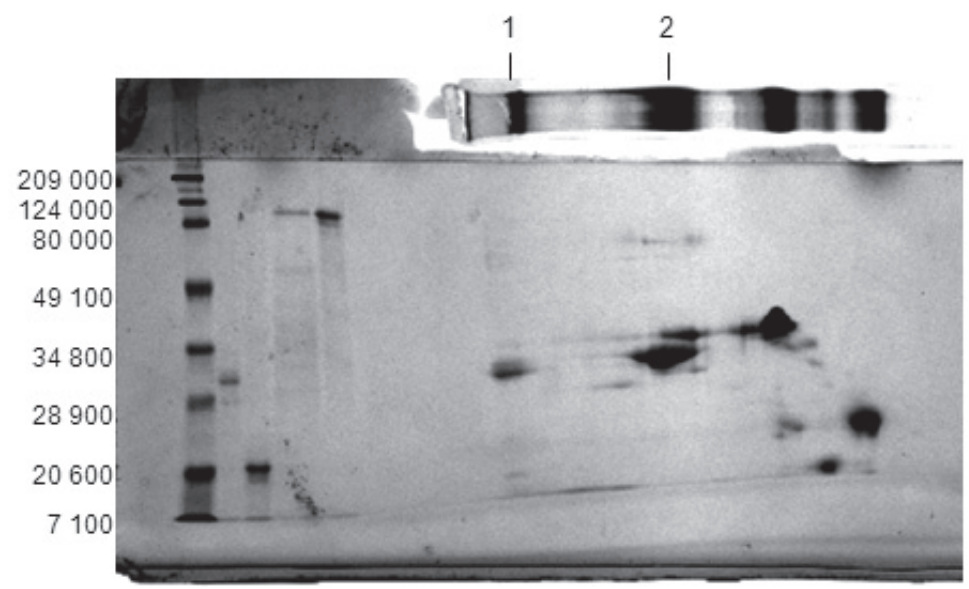

Figure 2. Two-dimensional alkaline/SDS-PAGE of reconstituted low heat NFDM without cysteine (A) and with cysteine (B). For all gels, lanes: $1=$ molecular mass standards (in $\mathrm{g} \cdot \mathrm{mol}^{-1}$ ), $2=\kappa$-casein, 3 = $\beta$-lactoglobulin, 4 = plasmin, 5 = plasminogen.

or whey proteins than with another PG molecule. Whey and casein agglomerates have been reported previously in NFDM [22, 31]; however, this is the first report that suggests $\mathrm{PG}$ could be present in such agglomerates. No differences in band patterns were apparent between the MH samples with and without cysteine (data not shown), which was consistent with absence of PG-derived PL activity in the two samples.

\subsection{Study 2: Storage study of reconstituted non-fat dry milk}

TPC on reconstituted NFDM samples were $<1 \mathrm{CFU} \cdot \mathrm{mL}^{-1}$ at both the beginning and end of storage studies at $4{ }^{\circ} \mathrm{C}$ and $21{ }^{\circ} \mathrm{C}$ (data not shown). Thus, any proteolysis observed in the samples was likely not due to bacterial proteases, but rather the result of indigenous enzymatic activity. Though PL exhibits proteolytic 
activity against $\beta$-casein, other native milk enzymes such as cathepsin D and cysteine protease have been shown to degrade milk proteins [29].

Plasmin and PG-derived PL activities for reconstituted NFDM samples stored at $21{ }^{\circ} \mathrm{C}$ and $4{ }^{\circ} \mathrm{C}$ are shown in Figure 3. Cysteine reduced $\mathrm{PG}$ activation over time in LH-NFDM with and without uPA at both storage temperatures. Little PL or PG-derived PL activities were detected in MH-NFDM, likely due to disulfide interactions between milk proteins, as previously discussed. It is relevant that cysteine decreases PG activation, especially in the presence of exogenous uPA, as several studies have confirmed that uPA are heat stable and associated with somatic cells $[11,13]$. This implies that milk with higher somatic cell counts has a greater propensity for PL-induced proteolysis, even after pasteurization. Even though milk does contain PL inhibitors, which have recently been shown to be more heat stable than previously thought, PG activation into greater quantities of PL can overcome the competitive inhibition afforded by PL inhibitors [23].

For PL activity in samples stored at $21{ }^{\circ} \mathrm{C}$, the main effects of heat treatment, uPA addition, and time and all interactions were significant $(P \leqslant 0.05)$, but cysteine addition was not significant. However, all main effects and interactions were significant for samples stored at $4{ }^{\circ} \mathrm{C}(P \leqslant$ $0.05)$. Plasminogen activation occurs at a much slower rate under refrigerated conditions [28], yielding less active PL and increasing the relative effect observed due to cysteine addition. For PG-derived PL activity in samples stored at $21^{\circ} \mathrm{C}$, the model was not significant $(P>0.05)$, although decreases in activity were shown for all LH samples, regardless of cysteine and uPA addition, complimenting the increases observed in PL activity (Fig. 3B). All main effects and interactions were significant for samples stored at $4{ }^{\circ} \mathrm{C}(P \leqslant 0.05)$.
Urea-PAGE of samples stored at $21{ }^{\circ} \mathrm{C}$ clearly showed increased proteolysis over time in LH control samples (Fig. 4A) because of the increase in PG activation and subsequent PL activity. Cysteine greatly decreased proteolysis in LH samples, leaving more $\beta$-casein than present in control samples, even in the presence of exogenous uPA (Fig. 4A). Similar trends were observed in samples stored at $4{ }^{\circ} \mathrm{C}$ (Fig. 4B), although proteolysis was less severe. Little or no proteolysis was apparent in any MH-NFDM samples, regardless of storage temperature, cysteine addition, and uPA addition. Residual $\beta$-casein remaining in samples stored at $21{ }^{\circ} \mathrm{C}$ and $4{ }^{\circ} \mathrm{C}$ is shown in Figure 5. While the model was not significant for either temperature $(P>0.05)$, the decreases in $\beta$-casein content over time clearly compliment the increases observed in PL activity (Fig. 3).

Several studies have been conducted on the effect of heat treatment on PL enzyme system in fluid milk, including the effect of various UHT preheat treatments on PL-like proteolysis in reconstituted LH-NFDM [19]. However, this is the first report of directly measuring PL activity and PG activation in NFDM of different heat classifications. It is clear from this study that PG activation occurs in reconstituted NFDM, which increases PL activity to result in greater proteolysis. This also is the first report that cysteine decreases indigenous enzymatic activity in NFDM, thus reducing proteolysis. This finding is especially important considering that NFDM is added to several food formulations in which enzymatic activity could have potentially adverse effects on product quality.

\section{CONCLUSIONS}

This study measured PL and PGderived PL activities in both $\mathrm{LH}$ and $\mathrm{MH}-$ NFDM and the fluid milk from which 


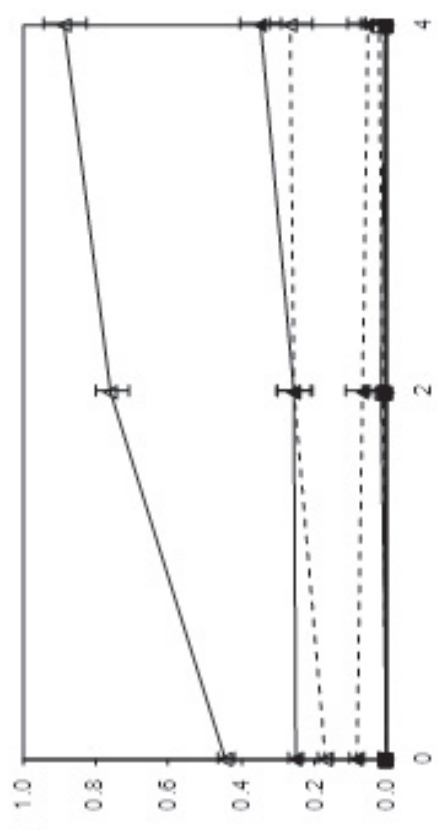

๑ิ (เ-7u-6nl) าd

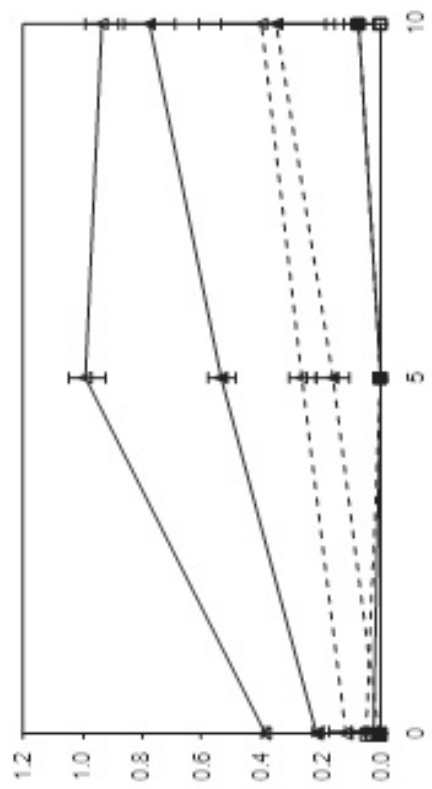

4

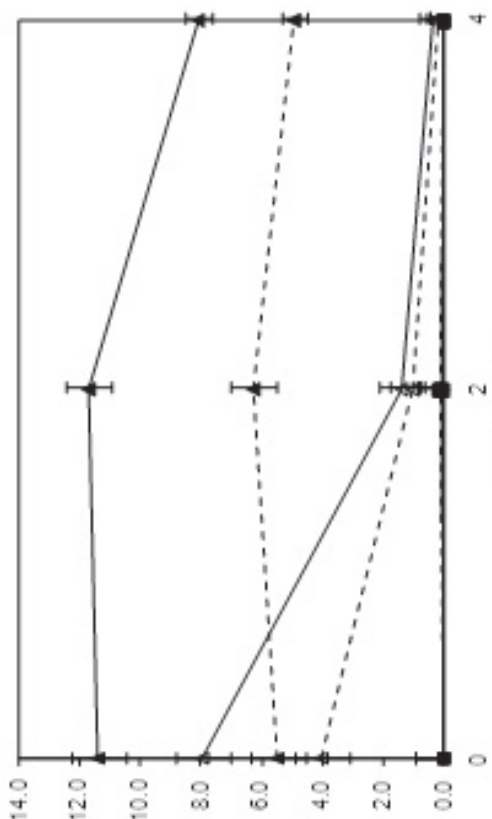

(เ-7u-61) רd pon!̣ag-פd

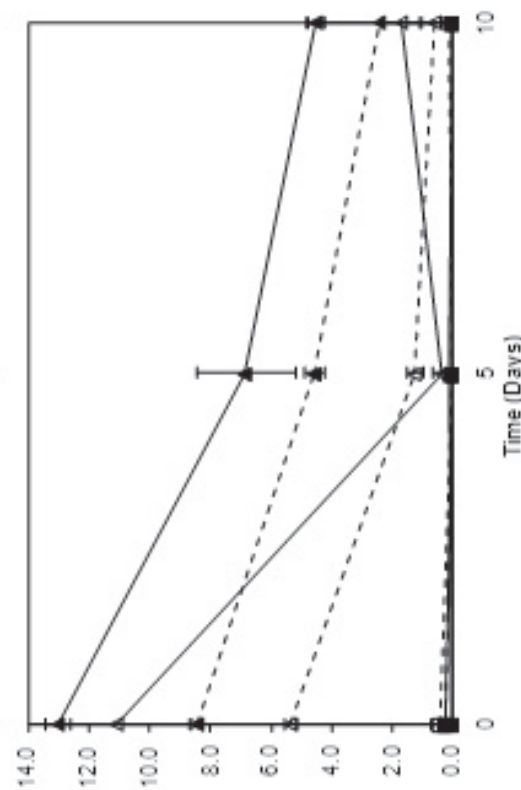

(1. Tur-Bil) רd pan!.-.90-כd

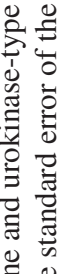

$\stackrel{\Xi}{*}$

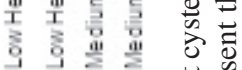

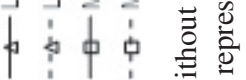

范

ฮ

를

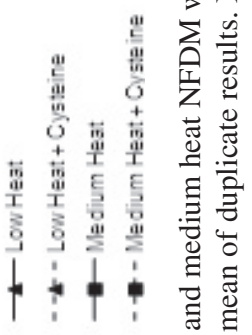

글 올

$\overrightarrow{7}$

造

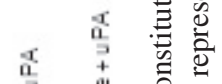

ชु.

$\stackrel{\circlearrowright}{\Xi}$

.

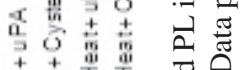

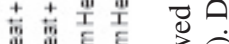

포 호 है

言言恶恶到

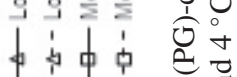

뉼

$\stackrel{0}{0} \varangle$

寻

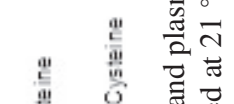

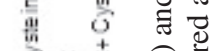

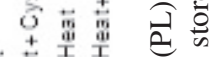

薷票至气

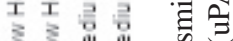

言言望望 至

$\uparrow+1 ! \frac{\pi}{2}$ 范 


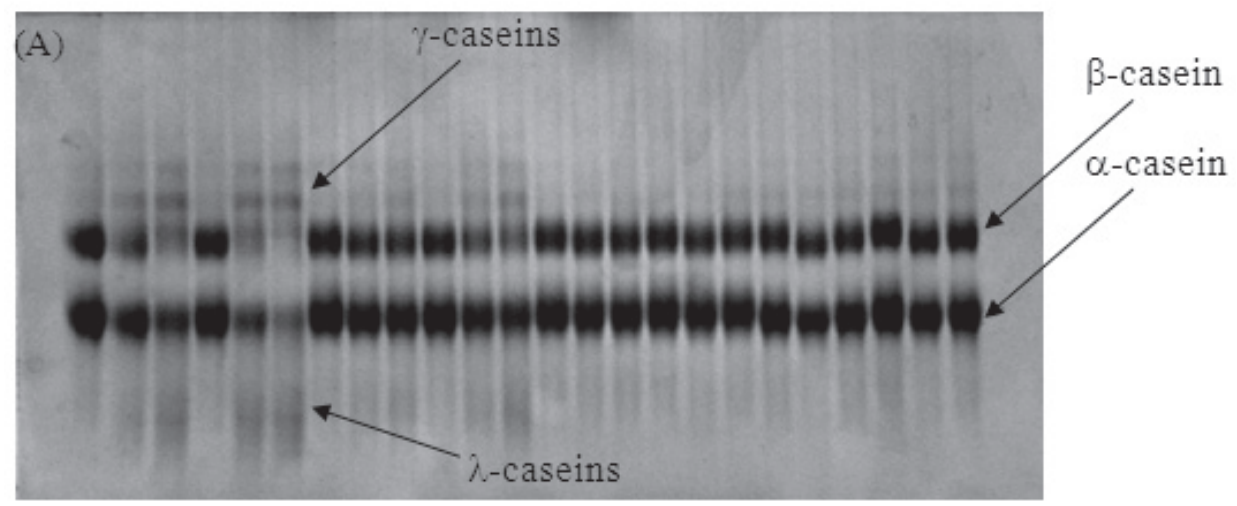

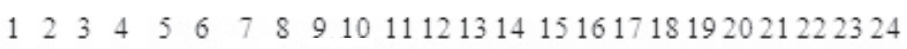

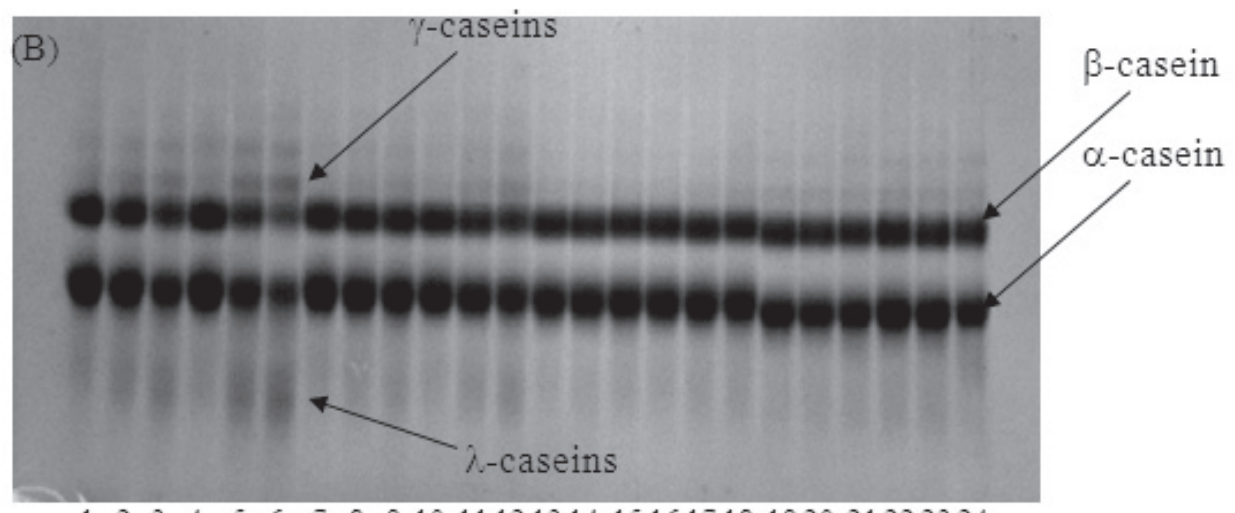

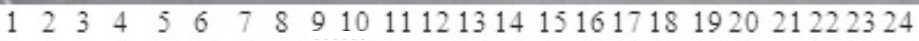

Figure 4. Urea-PAGE of reconstituted low heat (LH) and medium heat (MH) NFDM samples with and without cysteine and urokinase-type plasminogen activator (uPA) stored at $21{ }^{\circ} \mathrm{C}$ (A) and $4{ }^{\circ} \mathrm{C}(\mathrm{B})$. Every three lanes represents samples stored for 0,5 , and 10 days at $21^{\circ} \mathrm{C}$ or 0,2 , and 4 weeks at $4{ }^{\circ} \mathrm{C}$. Lanes: $1-3=\mathrm{LH}, 4-6=\mathrm{LH}+\mathrm{uPA}, 7-9=\mathrm{LH}+$ cysteine, $10-12=\mathrm{LH}+$ cysteine $+\mathrm{uPA}, 13-15=\mathrm{MH}, 16-18=\mathrm{MH}+\mathrm{uPA}, 19-21=\mathrm{MH}+$ cysteine, 22-24 $=\mathrm{MH}+$ cysteine + uPA.

it was made. While LH samples exhibited enzymatic activity, none was detected in $\mathrm{MH}$ samples, due to induced disulfide bonding between PL, PG, and milk proteins. It is possible that the addition of cysteine induced thiol-disulfide interchange reactions at lower heating temperatures, thus decreasing observed PL and PG-derived PL activities in LH samples, while not affecting the already undetectable activity in MH samples. Storage studies showed that PG conversion to active PL occurred over time in LH samples, which increased with the addition of exogenous uPA, while cysteine reduced PL activity over time. Proteolysis results 

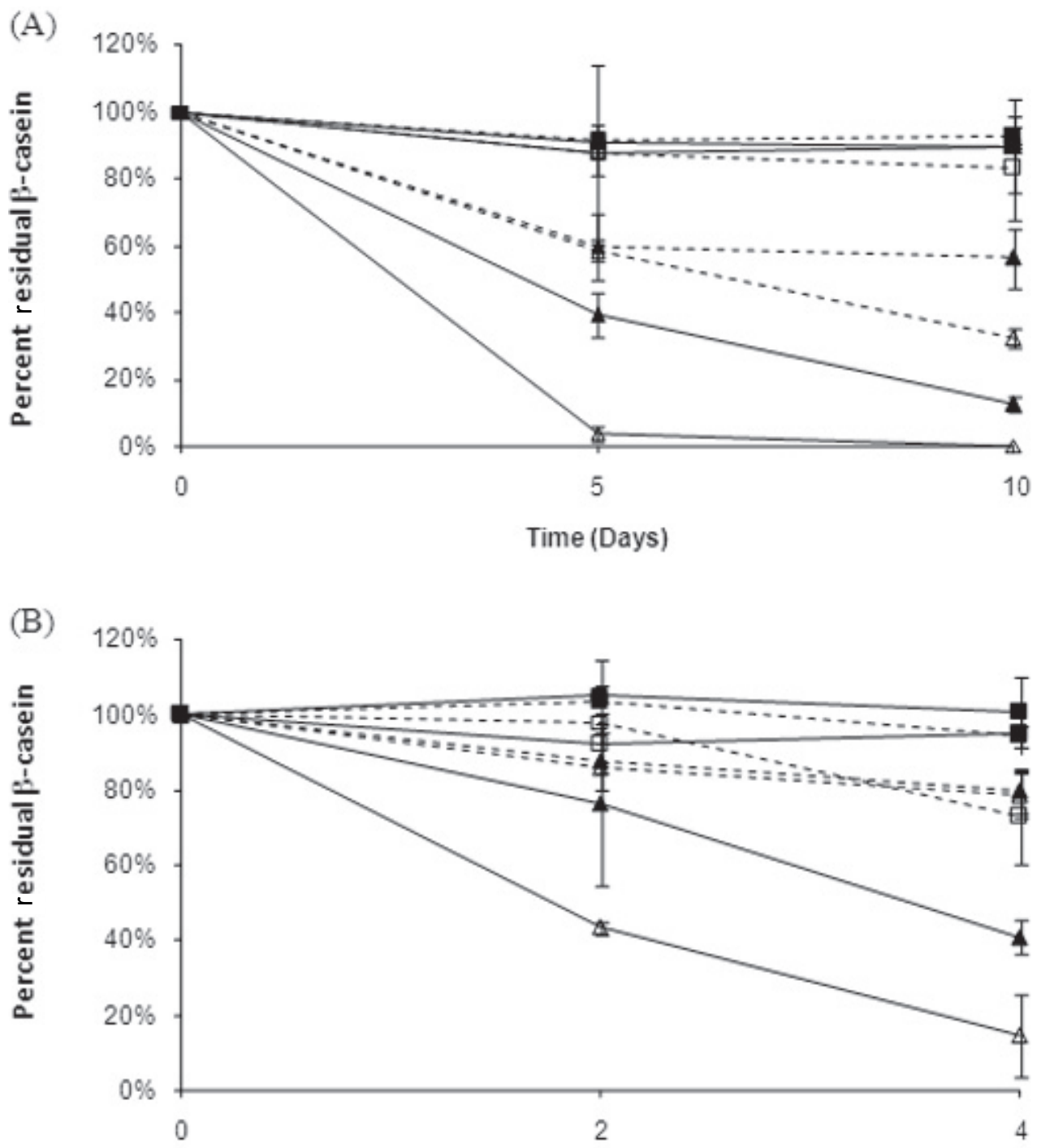

Time (Weeks)
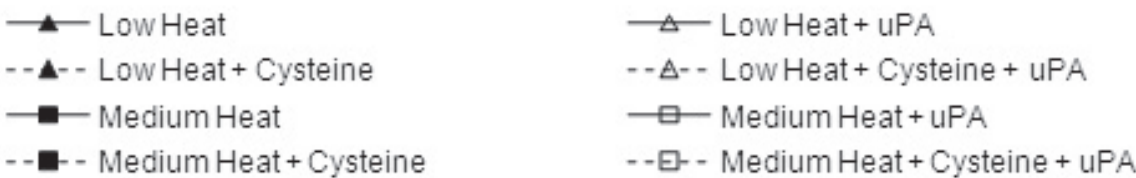

Figure 5. Percent residual $\beta$-casein in reconstituted low and medium heat NFDM with and without cysteine and urokinase-type PG activator (uPA) stored at $21{ }^{\circ} \mathrm{C}(\mathrm{A})$ and $4{ }^{\circ} \mathrm{C}$ (B). Data points represent the mean of duplicate results. Error bars represent the standard error of the mean. 
complemented the observed increases in PG activation and PL activity, demonstrating that cysteine decreases proteolysis due to PL and PG present in reconstituted NFDM. These results imply that the addition of cysteine prior to the pasteurization and manufacture of LH NFDM is an effective means of decreasing the potential for PL-induced proteolysis in any product to which LH-NFDM is added.

Acknowledgements: The authors thank R. R. Bello for his assistance and S. Knapp for her statistical advice. This work was supported by grant $05-35503-16118$ of the USDA.

\section{REFERENCES}

[1] Alichanidis E., Wrathall J.H.M., Andrews A.T., Heat stability of plasmin (milk proteinase) and plasminogen, J. Dairy Res. 53 (1986) 259-269.

[2] American Dairy Products Institute, Bulletin 916: Standards for Grades of Dry Milks Including Methods of Analysis, Elmhurst, IL, USA, 2006.

[3] Andrews A.T., Proteinases in normal bovine milk and their action on caseins, J. Dairy Res. 50 (1983) 45-55.

[4] AOAC, Official Methods of Analysis, 17th edn., Association of Official Analytical Chemists International, Gaithersburg, MD, USA, 2000.

[5] Bastian E.D., Brown R.J., Plasmin in milk and dairy products: an update, Int. Dairy J. 6 (1996) 435-447.

[6] Bastian E.D., Lo C.G., David K.M.M., Plasminogen activation in cheese milk: influence on Swiss cheese ripening, J. Dairy Sci. 80 (1997) 245-251.

[7] Burbrink C.N., Hayes K.D., Effect of thermal treatment on the activation of bovine plasminogen, Int. Dairy J. 16 (2006) 580585.

[8] Fajardo-Lira C., Nielsen S.S., Effect of psychrotrophic microorganisms on the plasmin system in milk, J. Dairy Sci. 81 (1998) 901908.

[9] Fajardo-Lira C., Oria M., Hayes K.D., Nielsen S.S., Effect of psychrotrophic bacteria and of an isolated protease from
Pseudomonas fluorescens M3/6 on the plasmin system of fresh milk, J. Dairy Sci. 83 (2000) 2190-2199.

[10] Gassem M.A., Frank J.F., Physical properties of yogurt made from milk treated with proteolytic enzymes, J. Dairy Sci. 74 (1991) 1503-1511.

[11] Gilmore J.A., White J.H., Zavizion B., Politis I., Effects of stage of lactation and somatic cell count on plasminogen activator activity in bovine milk, J. Dairy Sci. 62 (1995) 141-145.

[12] Havea P., Singh H., Creamer L.K., Campanella O.H., Electrophoretic characterization of the protein products formed during heat treatment of whey protein concentrate solutions, J. Dairy Res. 65 (1998) 79-91.

[13] Kelly A.L., Foley J., Proteolysis and storage stability of UHT milk as influenced by milk plasmin activity, plasmin/ $\beta$-lactoglobulin complexation, plasminogen activation and somatic cell count, Int. Dairy J. 7 (1997) 411-420.

[14] Kelly A.L., O'Connell J.E., Fox P.F., Manufacture and properties of milk powders, in: Fox P.F., McSweeney P.L.H. (Eds.), Advanced Dairy Chemistry Volume I: Proteins (3rd edn.), Kluwer Academic/Plenum Publishers, New York, NY, USA, 2003, pp. 1027-1061.

[15] Kohlmann K.L., Nielsen S.S., Ladisch M.R., Effects of a low concentration of added plasmin on ultra-high temperature processed milk, J. Dairy Sci. 74 (1991) 1151-1156.

[16] Larson N.K., Ismail B., Nielsen S.S., Hayes K.D., Activity of Bacillus polymyxa protease on components of the plasmin system in milk, Int. Dairy J. 16 (2006) 586-592.

[17] Manderson G.A., Hardman M.J., Creamer L.K., Effect of heat treatment on the conformation and aggregation of $\beta$-lactoglobulin $\mathrm{A}$, B, and C, J. Agric. Food Chem. 46 (1998) 5052-5061.

[18] Metwalli A.A.M., de Jongh H.H.J., van Boekel M.A.J.S., Heat inactivation of bovine plasmin, Int. Dairy J. 8 (1998) $47-56$.

[19] Newstead D.F., Paterson G., Anema S.G., Coker C.J., Wewala A.R., Plasmin activity in direct-steam-injection UHT-processed reconstituted milk: effects of preheat treatment, Int. Dairy J. 16 (2006) 573-579.

[20] Nielsen S.S., Plasmin system and microbial proteases in milk: characteristics, role, and 
relationship, J. Agric. Food Chem 50 (2002) 6628-6634.

[21] Oldfield D.J., Taylor M.W., Singh H., Effect of preheating and other process parameters on whey protein reactions during skim milk powder manufacture, Int. Dairy J. 15 (2005) 501-511.

[22] Parris N., White A.E., Farrell Jr. H.M., Identification of altered proteins in nonfat dry milk powder prepared from heat-treated skim milk, J. Agric. Food Chem 38 (1990) 824-829.

[23] Prado B.M., Sombers S.E., Ismail B., Hayes K.D., Effect of heat treatment on the activity of inhibitors of plasmin and plasminogen activators in milk, Int. Dairy J. 16 (2006) 593 599.

[24] Richardson B.C., The proteinases of bovine milk and the effect of pasteurization on their activity, N. Z. J. Dairy Sci. Technol 18 (1983) 233-252.

[25] Richardson B.C., Pearce K.N., The determination of plasmin in dairy products, N. Z. J. Dairy Sci. Technol. 16 (1981) 209-220.
[26] Saint Denis T., Humbert G., Gaillard J.-L., Heat inactivation of native plasmin, plasminogen and plasminogen activators in bovine milk: a revisited study, Lait 81 (2001) 715-729.

[27] SAS Institute, Inc., The SAS System for Windows, Version 9.1, Cary, NC, USA, 2003.

[28] Schroeder D.L., The effect of refrigerated storage on pasteurized milk and plasmin system, M.S. thesis, Purdue University, 2006.

[29] Somers J.M., O’Brien B., Meany W.J., Kelly A.L., Heterogeneity of proteolytic enzyme activities in milk samples of different somatic cell count, J. Dairy Res. 70 (2003) 45-50.

[30] Stevenson C.D., Effects of heat and cysteine on plasmin and plasminogen in buffer and milk, M.S. thesis, Purdue University, 2007.

[31] Ward B.R., Goddard S.J., Augustin M.A., McKinnon I.R., Distribution of proteins in concentrated skim milk reconstituted from low- and high-heat milk powders, J. Dairy Res. 63 (1996) 643-648. 